\title{
Clinicopathologic characteristics and survival of patients with double primary malignancies: breast and colorectal
} cancer

\author{
Hyundo Lee ${ }^{1, \star}$, Hae Won Lee ${ }^{2, \star}$, Eun Jung Park ${ }^{3}$, Jeonghyun Kang ${ }^{3}$, Seung Hyuk Baik ${ }^{3}$ \\ ${ }^{1}$ Department of Surgery, Yonsei University College of Medicine, Seoul; ${ }^{2}$ Department of Surgery, Asan Medical Center, University of Ulsan \\ College of Medicine, Seoul; ${ }^{3}$ Division of Colon and Rectal Surgery, Department of Surgery, Gangnam Severance Hospital, Yonsei University \\ College of Medicine, Seoul, Korea
}

Purpose: This study aimed to investigate the clinicopathologic features and survival in patients with both breast cancer $(\mathrm{BrC})$ and colorectal cancer (CRC).

Methods: Between 1996 and 2019, patients who were diagnosed with both $\mathrm{BrC}$ and $\mathrm{CRC}$ were evaluated retrospectively. Patients with distant metastasis, palliative resection, and previous cancer histories except for BrCs or CRCs were excluded. Altogether, 105 patients were divided into the $B=C$ group $(n=21)$, B-first group $(n=40)$, and C-first group $(n=44)$ according to the definition of synchronous and metachronous cancers. The clinicopathologic features and overall survival were evaluated.

Results: TNM stages and histologic types were comparable among the 3 groups $(\mathrm{P}=0.434)$. The interval of diagnosis was 67.1 \pm 40.4 and $59.3 \pm 47.2$ months in the B- and C-first groups, respectively. The incidence of adjuvant chemotherapy in the $\mathrm{B}$-first group was $57.5 \%$, which was higher than the $\mathrm{B}=\mathrm{C}$ and $\mathrm{C}$-first groups $(\mathrm{P}<0.001)$. The estrogen receptor, progesterone receptor, Ki-67, and HER-2 molecular markers were not significantly different among the groups. The overall survival of the B-first group showed lower survival rates than the $\mathrm{C}$-first group $(\mathrm{P}=0.039)$. In the logistic regression, HER-2 status (hazard ratio [HR], 11.9; $\mathrm{P}=0.032)$ and lymph node metastasis of $\mathrm{CRC}(\mathrm{HR}, 5.8 ; \mathrm{P}=0.036)$ were prognostic factors affecting overall survival.

Conclusion: B-first group had poorer survival outcomes than the C-first group in patients with the metachronous $\mathrm{BrC}$ and CRC. HER2 positivity and CRC lymph node metastasis may be prognostic factors that affect overall survival in these patients. The findings support that a colorectal cancer screening program should be included during $\mathrm{BrC}$ surveillance.

Keywords: Neoplasms; Breast neoplasms; Colorectal neoplasms; Survival

Received: Jul 27, 2021 - Revised: Aug 24, 2021 - Accepted: Aug 26, 2021

Correspondence to: Eun Jung Park, M.D., Ph.D., FACS

Division of Colon and Rectal Surgery, Department of Surgery, Yonsei

University College of Medicine, 211 Eonju-ro, Gangnam-gu, Seoul 06273, Korea

Tel: +82-2-2019-3897; Fax: +82-2-3462-5994

E-mail:camp79@yuhs.ac

ORCID: https://orcid.org/0000-0002-4559-2690

*Hyundo Lee and Hae Won Lee contributed equally to this work as co-first authors.

- This study was presented as a podium presentation of SISSO 2021 (June 25-26, 2021; Seoul, Korea) on 26 June 2021.

(C) 2022 The Korean Society of Coloproctology

This is an open-access article distributed under the terms of the Creative Commons Attribution NonCommercial License (https://creativecommons.org/licenses/by-nc/4.0) which permits unrestricted noncommercial use, distribution, and reproduction in any medium, provided the original work is properly cited.

\section{INTRODUCTION}

The survival of cancer patients has significantly improved through advances in cancer treatment and early diagnosis. However, patient survival in cases with multiple primary cancers which occur simultaneously is not yet known. Multiple primary cancers are defined as more than one cancer in the same individual and are classified by the time of occurrence of each cancer. Synchronous cancer is defined as each cancer occurring simultaneously or within a period of 6 months, while metachronous cancer is defined as being diagnosed with secondary cancer 6 months or more after the primary cancer diagnosis [1]. In epidemiological studies, the frequency of multiple primary cancers is reported 
to be in the range of approximately $2 \%$ to $17 \%[2,3]$.

Breast cancer $(\mathrm{BrC})$ and colorectal cancer (CRC) are the most common malignancies in women except for thyroid cancer $[4,5]$. There have been several studies on the possibilities of association between $\mathrm{BrC}$ and $\mathrm{CRC}$, especially about the incidence of CRC in $\mathrm{BrC}$ patients. Some studies have reported that $\mathrm{BrC}$ increases the risk of CRC [6-9] and vice versa [10-12]. Recent studies reported related genetic factors in patients with the BrC-CRC phenotype [13]. Fisher et al. [14] reported the outcomes of patients who are diagnosed with both breast and CRC using SEER (Surveillance, Epidemiology, and End Results) data. However, the SEER database does not contain many variables, which affect survival. Since these 2 cancers are the leading causes of cancer deaths in women, it is necessary to investigate the incidence and prognosis of patients diagnosed with both cancers. Thus, we aimed to investigate the clinicopathologic features and prognosis of patients who were diagnosed with breast and CRC synchronously or metachronously.

\section{METHODS}

\section{Study population and definition of double primary cancers} Between July 1996 and March 2019, there were 20,714 patients who were diagnosed with $\mathrm{BrC}$ in the Severance Hospital and Gangnam Severance Hospital, Seoul, Korea. Among them, 166 patients who were also diagnosed with CRC were evaluated retrospectively. Patients who did not undergo curative resection were histologically not confirmed or had metastases at the time of diagnosis. Patients who were diagnosed with both breast and CRC synchronously within 6 months were defined as belonging to the $\mathrm{B}=\mathrm{C}$ group. $\mathrm{BrC}$ patients who were diagnosed with $\mathrm{CRC}$ more than 6 months later were defined as the B-first group, while the
CRC patients who were diagnosed with $\mathrm{BrC}$ at least 6 months later were defined as the C-first group (Fig. 1). A total of 105 patients were divided into the $\mathrm{B}=\mathrm{C}$ group of 21 patients and metachronous groups of 84 patients according to the time of diagnosis of each cancer. Among the metachronous double primary cancer patients, there were 40 patients in the B-first group and 44 patients in the C-first group (Fig. 2). Data were gathered from the electronic medical recording system of Yonsei University Health System and were analyzed retrospectively. The study was carried out in accordance with the Declaration of Helsinki and was approved by the Institutional Review Board of Gangnam Severance Hospital (No. 3-2021-0165) with a waiver for informed consent.

\section{Evaluation of the clinicopathological parameters}

The data of patient characteristics were collected such as sex, age at diagnosis, body mass index (BMI) at diagnosis, comorbidities, past medical histories, and family histories. Clinicopathologic variables related to $\mathrm{BrC}$ such as tumor location, type of histology, T stage, lymph nodes (LN) metastasis, type of adjuvant treatments, TNM stage, estrogen receptor (ER), progesterone receptor (PR), Ki-67, human epidermal growth factor receptor 2 (HER2), and type of molecular classification were especially noted. In the case of CRC, tumor location, type of surgical treatment, histologic differentiation, T stage, LN metastasis, and TNM stage were evaluated. Molecular classification of $\mathrm{BrC}$ was performed using the surrogate definitions from St. Gallen Consensus 2013 [15]. TNM stage of each cancer was determined according to American Joint Committee on Cancer cancer stage manual, 8th edition [16].

\section{Statistical methods}

The associations of the 3 different groups and the continuous variables were evaluated using analysis of variance or independent

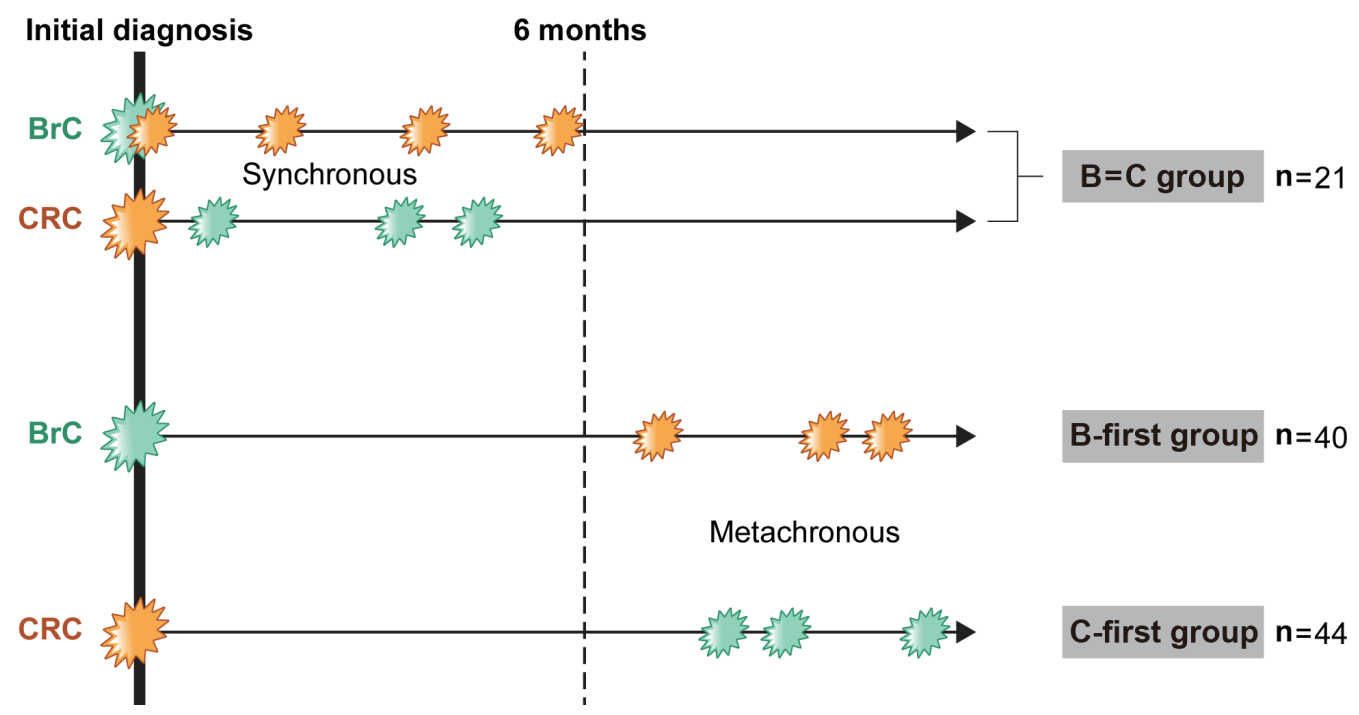

Fig. 1. Diagram for the definition of the study group. BrC, breast cancer; CRC, colorectal cancer. 


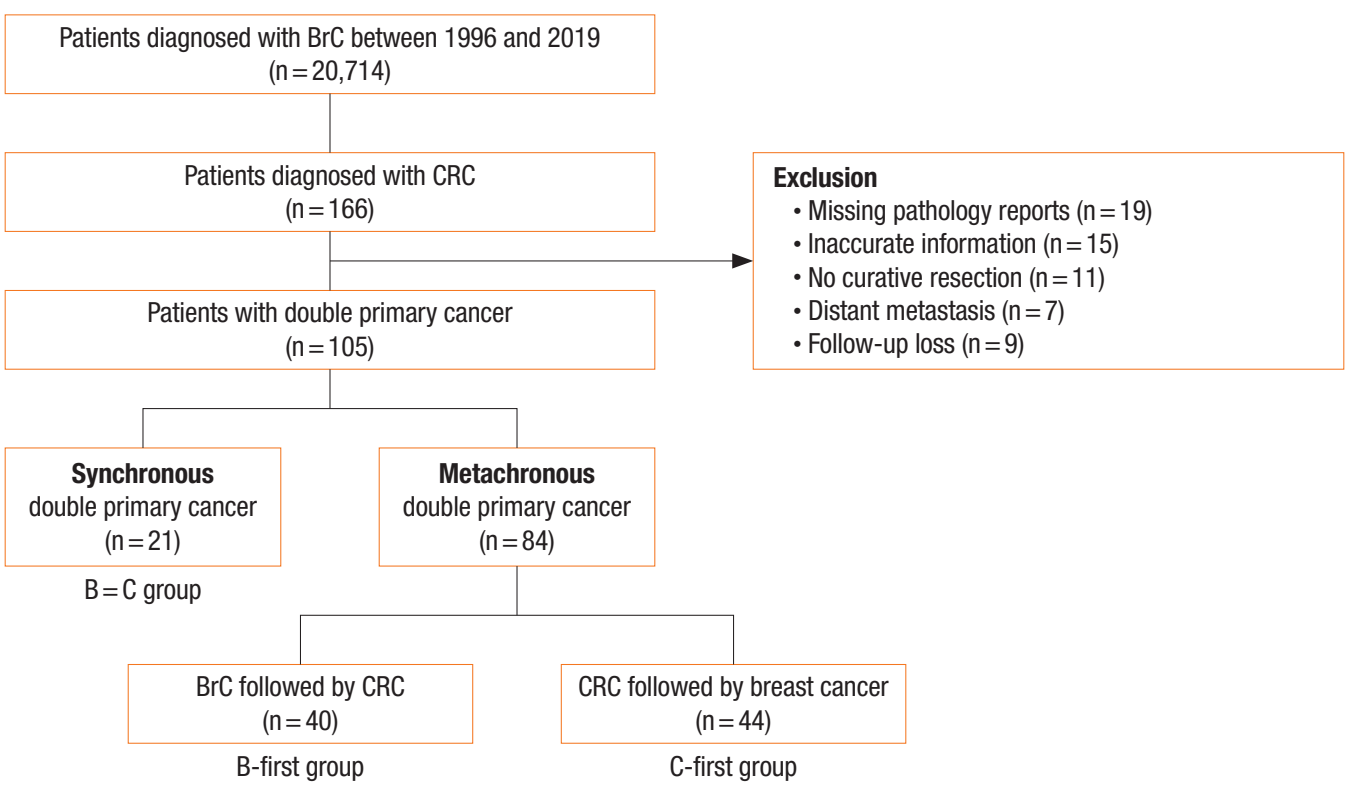

Fig. 2. Flow chart of the study. BrC, breast cancer; CRC, colorectal cancer.

2-sample t-test. The chi-square or Fisher exact test was used to compare clinicopathological characteristics of patients for dichotomous variables. Overall survival was calculated from the date of diagnosis of the first cancer. Survival curves were plotted using the Kaplan-Meier method, and group differences in survival were evaluated by the log-rank test. Cox proportional hazard model was used to identify variables that were independently associated with overall survival. All statistical tests were 2 -sided, and $\mathrm{P}<0.05$ was considered statistically significant. Statistical analyses were carried out using the IBM SPSS Statistics ver. 25.0 (IBM Corp., Armonk, NY, USA).

\section{RESULTS}

\section{Patient characteristics}

In the C-first group, there was only 1 male patient. The mean ages at diagnosis of the first primary cancer were 63.0 years in patients of the $\mathrm{B}=\mathrm{C}$ group, 57.0 years for the B-first group, and 59.6 years for the $\mathrm{C}$-first group. The ages upon diagnosis of the second primary cancer were 62.5 years in the B-first group and 64.7 years in the C-first group. There were no significant differences among the 3 groups regarding the age upon diagnosis of both the first and second primary cancers. The intervals of diagnosis between breast and CRC were 67.1 months in the B-first group and 59.3 months in C-first group. While the patients of the B-first group had higher rates of diabetes mellitus, there was no significant difference for BMI, previous cancer histories, and familial cancer histories among the groups. Carcinoembryonic antigen (CEA) level at the diagnosis of $\mathrm{BrC}$ in the $\mathrm{B}=\mathrm{C}$ group was $8.1 \mathrm{ng} / \mathrm{mL}$ and $8.5 \mathrm{ng} / \mathrm{mL}$ for CRC. Tumor markers for CEA and carcinoma antigen 15-3 at the diagnosis of $\mathrm{BrC}$ and CRC were significantly different among the groups (Table 1).

\section{Clinicopathological characteristics of breast cancer}

The tumor location of $\mathrm{BrC}$ was not significantly different among the groups. There was 1 patient each with bilateral $\mathrm{BrC}$ in both the B-first group and the C-first group. Invasive ductal carcinoma was the most common histologic type in all groups. T1 stage for $\mathrm{BrC}$ was $52.4 \%, 45.0 \%$, and $61.4 \%$ for the $\mathrm{B}=\mathrm{C}$ group, $\mathrm{B}$-first group, and C-first group, respectively. The rate of $\mathrm{LN}$ metastasis was $14.3 \%, 32.5 \%$, and $20.5 \%$ for the $\mathrm{B}=\mathrm{C}$ group, B-first group, and C-first group, respectively. For the TNM stage, stage I was most the common, followed by stage II for BrC. In the B-first group, $57.5 \%$ received chemotherapy, which was higher than the $\mathrm{B}=\mathrm{C}$ or $\mathrm{C}$-first group $(\mathrm{P}<0.001)$. The expression of $\mathrm{ER}, \mathrm{PR}$, and HER2 and the median value of Ki-67 were not significantly different among the 3 groups. For the molecular classification, the rate of patients with triple negative was $60.0 \%$ in the C-first group, $30 \%$ in the $\mathrm{B}$-first group, and $9.5 \%$ in the $\mathrm{B}=\mathrm{C}$ group. However, there was no significant difference for molecular classification among groups (Table 2).

\section{Clinicopathological characteristics of colorectal cancer}

Regarding tumor location of CRC, a left-sided tumor involving rectal cancer was more common than right-sided cancer. The rate of rectal cancer was $23.8 \%, 37.5 \%$, and $40.9 \%$ for the $\mathrm{B}=\mathrm{C}$ group, $\mathrm{B}$-first group, and C-first group, respectively. In the B-first group, $20 \%$ of the patients were treated by endoscopic submucosal resection, while for the $\mathrm{B}=\mathrm{C}$ group and $\mathrm{C}$-first group, $95.2 \%$ and $95.5 \%$ received surgical treatments, respectively $(\mathrm{P}=0.044)$. Ade- 


\section{Coloproctology Hyundo Lee, et al.}

Table 1. Patients' characteristics

\begin{tabular}{|c|c|c|c|c|}
\hline \multirow{2}{*}{ Characteristic } & \multirow{2}{*}{$\begin{array}{l}\text { Synchronous, } \\
\mathrm{B}=\mathrm{C} \text { group }\end{array}$} & \multicolumn{2}{|c|}{ Metachronous } & \multirow{2}{*}{ P-value } \\
\hline & & B-first group & C-first group & \\
\hline No. of patients & 21 & 40 & 44 & \\
\hline Sex & & & & 0.497 \\
\hline Male & $0(0)$ & $0(0)$ & $1(2.3)$ & \\
\hline Female & $21(100)$ & $40(100)$ & $43(97.7)$ & \\
\hline \multicolumn{5}{|l|}{ Age $(y r)$} \\
\hline The first primary cancer & $63.0 \pm 9.9(43-82)$ & $57.0 \pm 10.1(34-73)$ & $59.6 \pm 10.5(33-78)$ & 0.093 \\
\hline The second primary cancer & $63.0 \pm 9.9(43-82)$ & $62.5 \pm 9.6(40-80)$ & $64.7 \pm 10.7(41-82)$ & 0.596 \\
\hline Interval between diagnosis of $\mathrm{BrC}$ and $\mathrm{CRC}$ (mo) & $0.5 \pm 1.3(0-5)$ & $67.1 \pm 40.4(7-183)$ & $59.3 \pm 47.2(6-223)$ & $>0.999$ \\
\hline $\mathrm{BMI}$ at diagnosis of the first cancer $\left(\mathrm{kg} / \mathrm{m}^{2}\right)$ & $23.2 \pm 2.8(19.4-30.4)$ & $23.5 \pm 3.5(17.2-31.6)$ & $24.2 \pm 4.1(16.5-32.8)$ & 0.540 \\
\hline \multicolumn{5}{|l|}{ Comorbidity } \\
\hline Hypertension & $5(23.8)$ & $19(47.5)$ & $19(43.2)$ & 0.187 \\
\hline Diabetes mellitus & $0(0.0)$ & $13(32.5)$ & $8(18.2)$ & 0.010 \\
\hline Previous cancer history & $1(4.8)$ & $6(15.0)$ & $6(13.6)$ & 0.487 \\
\hline \multicolumn{5}{|l|}{ Familial cancer history } \\
\hline $\mathrm{BrC}$ & $2(9.5)$ & $2(5.0)$ & $5(11.4)$ & 0.573 \\
\hline $\mathrm{CRC}$ & $2(9.5)$ & $1(2.5)$ & $4(9.1)$ & 0.405 \\
\hline Both & $0(0)$ & $0(0)$ & $1(2.3)$ & 0.480 \\
\hline Other cancers & $5(23.8)$ & $11(27.5)$ & $11(25.0)$ & 0.943 \\
\hline \multicolumn{5}{|l|}{ Tumor marker at $\mathrm{BrC}$ diagnosis } \\
\hline CEA $(n g / m L)$ & $8.1 \pm 11.4(0.5-41.3)$ & $2.1 \pm 1.4(0.5-5.8)$ & $4.0 \pm 11.8(0.6-73.9)$ & 0.112 \\
\hline CA 15-3 (U/mL) & $13.3 \pm 8.4(2.9-28.4)$ & $10.5 \pm 4.6(4.4-21.3)$ & $11.9 \pm 6.7(1.8-30.6)$ & 0.369 \\
\hline \multicolumn{5}{|l|}{ Tumor marker at CRC diagnosis } \\
\hline CEA (ng/mL) & $8.5 \pm 17.5(0.9-77.5)$ & $3.3 \pm 3.2(0.6-12.7)$ & $7.5 \pm 17.0(0.4-87.1)$ & 0.288 \\
\hline
\end{tabular}

Values are presented as mean \pm standard deviation (range) or number of patients (\%).

$\mathrm{BrC}$, breast cancer; CRC, colorectal cancer; BMI, body mass index; CEA, carcinoembryonic antigen; CA 15-3, carcinoma antigen 15-3.

nocarcinoma was the most common histologic type in all groups. $\mathrm{T} 3$ was the most common $\mathrm{T}$ stage, with no significant difference among the groups. The rate of regional LN metastasis was $42.9 \%$ in the $\mathrm{B}=\mathrm{C}$ group, $22.5 \%$ in the $\mathrm{B}$-first group, and $29.5 \%$ in the $\mathrm{C}$-first group. However, there were no significant differences in tumor location, treatment, histologic type, and TNM stages for CRC (Table 3).

\section{Survival outcomes}

The median follow-up period was 13.9 years. The survival outcomes of $\mathrm{B}=\mathrm{C}, \mathrm{B}$-first, and $\mathrm{C}$-first groups are shown in Fig. 3A. In the survival analysis for all groups, the survival of the B-first group was poorer than the other groups with marginal significance $(\mathrm{P}=0.054)$. In the post hoc analysis, the overall survival between the B-first and C-first groups was significantly different $(\mathrm{P}=0.039)$. In contrast, the $\mathrm{B}=\mathrm{C}$ group showed no significant difference in the survival outcomes with the B-first and C-first groups. In the survival comparisons between synchronous and metachronous cancers for $\mathrm{BrC}$ and $\mathrm{CRC}$, there were no statistically significant differences between the 2 groups $(P=0.319)$. In comparing the metachronous cancers between the B-first and Cfirst groups, the survival of the C-first group was better than the B-first group as shown in Fig. 3C $(\mathrm{P}=0.039)$. According to the TNM stages of CRC, there was no significant difference in survival among the 3 groups: stage I $(\mathrm{P}=0.407)$, stage II $(\mathrm{P}=0.346)$, and stage III $(\mathrm{P}=0.565)$ (Supplementary Fig. 1).

\section{Prognostic factors of overall survival}

In the univariate analysis for overall survival, there were no significant differences among the groups (hazard ratio [HR] of C-first group, 0.23 and $\mathrm{B}=\mathrm{C}$ group, $0.22 ; \mathrm{P}=0.086$ and $\mathrm{P}=0.364$, respectively). Ages at cancer diagnosis, tumor markers, histologic types, and TNM stages in both $\mathrm{BrC}$ and CRC showed no significant relations to overall survival. On the other hand, HER2 positivity increased the HR by 11.9 times for the overall survival $(\mathrm{P}=0.032)$. In addition, regional LN metastasis of CRC increased the HR by 
Table 2. Clinicopathologic outcomes of breast cancer

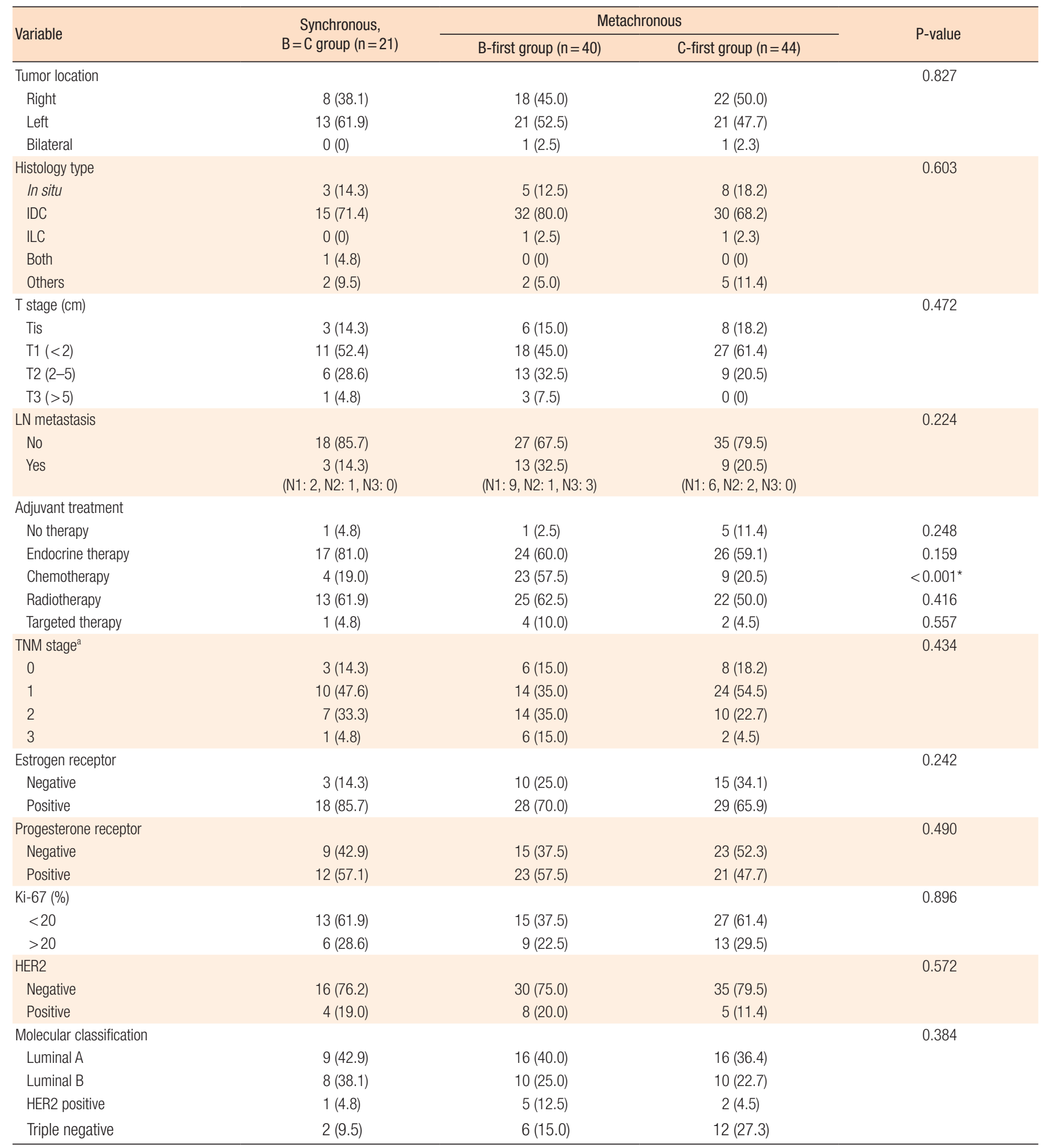

Values are presented as number of patients (\%).

IDC, invasive ductal carcinoma; ILC, invasive lobular carcinoma; LN, lymph node; HER2, human epidermal growth factor receptor 2.

astage according to American Joint Committee on Cancer cancer stage manual, 8th edition.

${ }^{*} \mathrm{P}<0.05$. 
Table 3. Clinicopathologic outcomes of colorectal cancer

\begin{tabular}{|c|c|c|c|c|}
\hline \multirow{2}{*}{ Variable } & \multirow{2}{*}{$\begin{array}{c}\text { Synchronous, } \\
B=C \text { group }(n=21)\end{array}$} & \multicolumn{2}{|c|}{ Metachronous } & \multirow{2}{*}{ P-value } \\
\hline & & B-first group $(n=40)$ & C-first group $(n=44)$ & \\
\hline Tumor location & & & & 0.194 \\
\hline Right-sided colon & $7(33.3)$ & $7(17.5)$ & $16(36.4)$ & \\
\hline Left-sided colon & $9(42.9)$ & $17(42.5)$ & $10(22.7)$ & \\
\hline Rectum & $5(23.8)$ & $15(37.5)$ & $18(40.9)$ & \\
\hline Appendix & $1(4.8)$ & $1(2.5)$ & $0(0)$ & \\
\hline Treatment & & & & $0.044^{*}$ \\
\hline Endoscopic treatment & $1(4.8)$ & $8(20.0)$ & $2(4.5)$ & \\
\hline Surgery & $20(95.2)$ & $32(80.0)$ & 42 (95.5) & \\
\hline Histologic type & & & & 0.247 \\
\hline Adenocarcinoma & $21(100)$ & $40(100)$ & $43(97.7)$ & \\
\hline Signet ring cell & $0(0)$ & $0(0)$ & $1(2.3)$ & \\
\hline T stage & & & & 0.604 \\
\hline Tis & $1(4.8)$ & $5(12.5)$ & $4(9.1)$ & \\
\hline $\mathrm{T} 1$ & $2(9.5)$ & $9(22.5)$ & $8(18.2)$ & \\
\hline T2 & $2(9.5)$ & 7 (17.5) & $7(15.9)$ & \\
\hline T3 & $13(61.9)$ & 15 (37.5) & $23(52.3)$ & \\
\hline T4 & $3(14.3)$ & $4(10.0)$ & $2(4.5)$ & \\
\hline LN metastasis & & & & 0.278 \\
\hline No & $12(57.1)$ & $31(77.5)$ & $31(70.5)$ & \\
\hline Yes & $\begin{array}{c}9(42.9) \\
(\mathrm{N} 1: 6, \mathrm{~N} 2: 3, \mathrm{~N} 3: 0)\end{array}$ & $\begin{array}{c}9(22.5) \\
(\mathrm{N} 1: 6, \mathrm{~N} 2: 3, \mathrm{~N} 3: 0)\end{array}$ & $\begin{array}{c}13(29.5) \\
(\mathrm{N} 1: 8, \mathrm{~N} 2: 5, \mathrm{~N} 3: 0)\end{array}$ & \\
\hline TNM stage & & & & 0.698 \\
\hline 0 & $1(4.8)$ & $5(12.5)$ & $4(9.1)$ & \\
\hline 1 & $4(19.0)$ & $14(35.0)$ & $14(31.8)$ & \\
\hline 2 & 7 (33.3) & $12(30.0)$ & $14(31.8)$ & \\
\hline 3 & $9(42.9)$ & $9(22.5)$ & $12(27.3)$ & \\
\hline
\end{tabular}

Values are presented as number of patients (\%).

LN, lymph node.

${ }^{*} \mathrm{P}<0.05$.

5.81 times $(\mathrm{P}=0.036)$. However, hormone receptors and the molecular classification of $\mathrm{BrC}$ showed no significant outcomes affecting the overall survival. In the multivariate analysis, the HR of HER2 positivity was 7.07 and 5.44 for the CRC LN metastasis. However, the values for these variables were not found to be statistically significant (Table 4).

\section{DISCUSSION}

This study focused on evaluating the clinicopathologic and oncologic outcomes for patients who were diagnosed with both $\mathrm{BrC}$ and CRC. In patients with metachronous $\mathrm{BrC}$ and $\mathrm{CRC}$ cancers, the B-first group showed poorer overall survival outcomes compared to the C-first group. In addition, HER2 positivity and CRC LN metastasis were regarded as prognostic factors that affect overall survival.

With the advancement of early diagnosis and treatment, the survival of cancer patients has improved. However, it is not common for various cancers to occur in 1 patient; cases such as these are classified as having multiple primary cancer. In the epidemiological studies, the frequency of multiple primary cancers is reported to be in the range of $2 \%$ to $17 \%[2,17]$. CRC and $\mathrm{BrC}$ incidence is increasing in women in Korea. Except for thyroid cancer, both cancers are considered the most common cancer types [18]. This trend may be due to the westernized lifestyle, delayed marriage, and low fertility rate $[19,20]$. This study analyzed 105 patients who were diagnosed with both $\mathrm{CRC}$ and $\mathrm{BrC}$ and divided them into synchronous and metachronous cancer patients. According to the International Association of Cancer Registries and International Agency for Research on Cancer standard, the syn- 


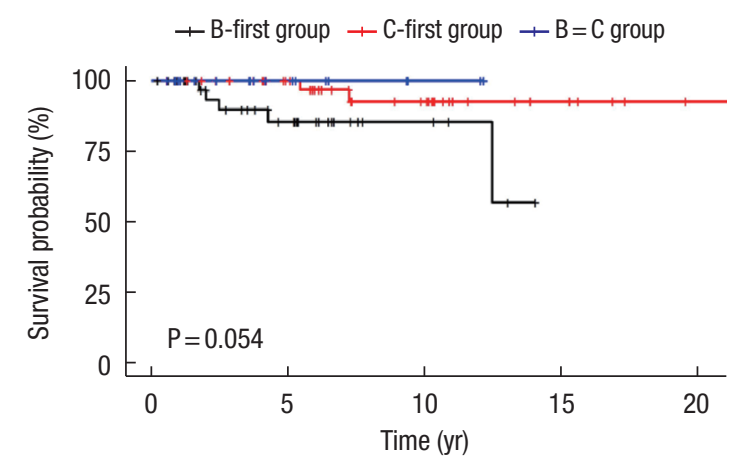

B-first group 40 C-first group 44 $\mathrm{B}=\mathrm{C}$ group 21

$\begin{array}{cccc}19 & 5 & 0 & 0 \\ 33 & 18 & 6 & 1 \\ 8 & 2 & 0 & 0\end{array}$

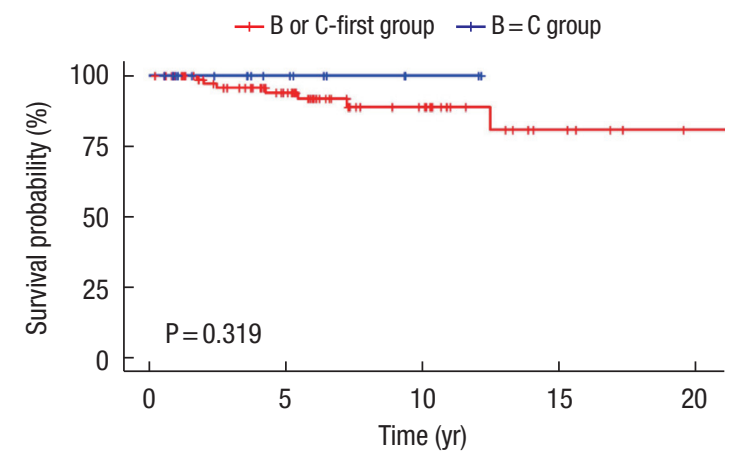

B or C-first group 84 $\mathrm{B}=\mathrm{C}$ group 21

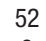

8

23

2

$\begin{array}{ll}6 & 1 \\ 0 & 0\end{array}$

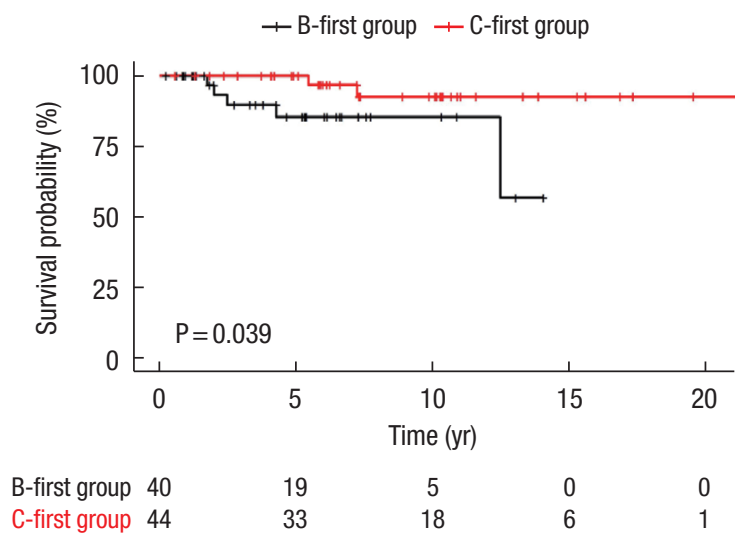

Fig. 3. Overall survival outcomes. (A) Comparison among all study groups $(\mathrm{P}=0.054)$. (B) Metachronous vs. synchronous cancers $(\mathrm{P}=$ 0.319). (C) Comparison between metachronous cancer $(\mathrm{P}=0.039)$.

chronous and metachronous standards were divided into 6 months [1]. Metachronous cancer patients were divided into the $\mathrm{BrC}$ first diagnosed group (B-first group) and the CRC first diagnosed group (C-first group).

Regarding the clinical characteristic of the 3 groups, the preva- lence of diabetes mellitus was significantly lower in the $\mathrm{B}=\mathrm{C}$ group $(\mathrm{P}=0.01)$. Because diabetes mellitus is associated with the poor outcomes of $\mathrm{BrC}$ and $\mathrm{CRC}$, it may influence the prognosis of the $\mathrm{B}=\mathrm{C}$ group $[21,22]$. In contrast, there was no significant difference among the groups in terms of hormonal receptors and pathologic results of BrC. However, in the treatment of CRC of the B-first group, higher rates of endoscopic resection were performed than surgical treatment. Considering the higher rates of receiving adjuvant chemotherapy for $\mathrm{BrC}$ in the $\mathrm{B}$-first group, these results may affect the poorer survival of the B-first group than the other groups as shown in Fig. 3.

In the survival analysis for double primary cancers of $\mathrm{BrC}$ and CRC, Fisher et al. [14] reported that the risk of death from CRC was nearly 3 times that of $\mathrm{BrC}$ from the analysis of SEER data for both $\mathrm{BrC}$ and $\mathrm{CRC}$. In this study, similar results were found; 4 cases of CRC-related deaths and 1 case of BrC-related death. Chapman et al. [23] reported that non-BrC-related deaths were more common than $\mathrm{BrC}$-specific deaths in $\mathrm{BrC}$ patients, and osteoporosis caused by endocrine therapy is associated with increased risk of death from other malignancies. Thus, it is considerable that treatment of CRC can be more overweighed than $\mathrm{BrC}$ in similar stages.

In this study, it was seen that the B-first group had poorer overall survival than the $\mathrm{C}$-first group. Though there were lower rates of surgical resection for CRC in the B-first group than in other groups ( $95.2 \%$ vs. $95.5 \%$ vs. $80.0 \%, \mathrm{~B}=\mathrm{C}$ vs. C-first vs. B-first groups; $\mathrm{P}=0.044$ ), early stages of $\mathrm{CRC}$, which were treated via endoscopic resection, might not affect survival outcomes. In addition, the B-first group showed poorer overall survival than the Cfirst group despite no significant difference in TNM stages for both $\mathrm{BrC}$ and $\mathrm{CRC}$. The selection bias limitation of our retrospective study might have influenced the poorer overall survival of the B-first group than of the C-first group (Fig. 3C). However, per the SEER data between 1988 and 2007 for patients with $\mathrm{BrC}$ and CRC, the cumulative risk of death was 3 times higher in CRC than in $\mathrm{BrC}$ because CRC-specific mortality increases while $\mathrm{BrC}$ specific mortality decreased with time [14]. They suggested that the second cancer diagnosis in double primary cancers is more related to the risk of death. Considering the poorer survival of the B-first group than of the C-first group in our study, CRC screening is recommended to be undertaken after $\mathrm{BrC}$ diagnosis.

In the univariate analysis from Cox regression, the predictive factors of overall survival were CRC LN metastasis and HER2 positivity for $\mathrm{BrC}$. LN metastasis of CRC is related to poor prognosis. Therefore, adjuvant chemotherapy is needed in patients with stage III CRC patients. In addition, the prognosis of $\mathrm{BrC}$ has improved when patients with HER2 positivity are given trastuzumab. In this study, HER2 positivity was one of the prognostic factors affecting overall survival in patients with double primary cancers of $\mathrm{BrC}$ and $\mathrm{CRC}$. In recent clinical trials, the expression of HER2 receptor is considered to treat metastatic CRC patients [24, 25]. Although further studies are required, HER2 expression can 
Hyundo Lee, et al.

Table 4. Univariate and multivariate analyses for overall survival

\begin{tabular}{|c|c|c|c|c|}
\hline \multirow{2}{*}{ Variable } & \multicolumn{2}{|c|}{ Univariate analysis } & \multicolumn{2}{|c|}{ Multivariate analysis } \\
\hline & $\mathrm{HR}(95 \% \mathrm{Cl})$ & P-value & $\mathrm{HR}(95 \% \mathrm{Cl})$ & P-value \\
\hline \multicolumn{5}{|l|}{ Group } \\
\hline B-first group & Reference & & Reference & \\
\hline C-first group & $0.23(0.04-1.23)$ & 0.086 & $0.28(0.03-2.30)$ & 0.235 \\
\hline $\mathrm{B}=\mathrm{C}$ group & $0.22(0.01-5.65)$ & 0.364 & $0.25(0.01-7.90)$ & 0.428 \\
\hline Age at $\mathrm{BrC}$ diagnosis & $0.98(0.92-1.05)$ & 0.615 & & \\
\hline Age at CRC diagnosis & $0.99(0.93-1.07)$ & 0.900 & & \\
\hline CEA at CRC diagnosis & $0.99(0.89-1.09)$ & 0.784 & & \\
\hline CA15-3 at BrC diagnosis & $0.98(0.84-1.15)$ & 0.804 & & \\
\hline \multicolumn{5}{|l|}{$\mathrm{BrC}$ histology } \\
\hline In situ cancer & Reference & & & \\
\hline IDC & $0.91(0.10-8.03)$ & 0.935 & & \\
\hline Others & $1.14(0.07-18.98)$ & 0.927 & & \\
\hline \multicolumn{5}{|l|}{ BrC T stage } \\
\hline T0 & Reference & & & \\
\hline $\mathrm{T} 1$ & $1.06(0.11-9.83)$ & 0.960 & & \\
\hline T2 & $0.49(0.03-8.34)$ & 0.620 & & \\
\hline T3 & $7.95(0.49-128.96)$ & 0.145 & & \\
\hline \multicolumn{5}{|l|}{ BrC LN metastasis } \\
\hline No & Reference & & & \\
\hline Yes & $2.01(0.44-9.17)$ & 0.368 & & \\
\hline \multicolumn{5}{|l|}{ Hormone receptor ${ }^{\mathrm{a}}$} \\
\hline Negative & Reference & & & \\
\hline Positive & $0.99(0.18-5.44)$ & 0.986 & & \\
\hline \multicolumn{5}{|l|}{ HER2 } \\
\hline Negative & Reference & & Reference & \\
\hline Positive & $11.93(1.24-115.08)$ & $0.032^{*}$ & $7.07(0.82-61.36)$ & 0.076 \\
\hline \multicolumn{5}{|l|}{ Molecular classification } \\
\hline Luminal A & Reference & & & \\
\hline Luminal B & $1.12(0.10-12.99)$ & 0.931 & & \\
\hline HER2 enriched & $8.71(0.88-86.44)$ & 0.065 & & \\
\hline Triple negative & $0.25(0.01-9.36)$ & 0.453 & & \\
\hline \multicolumn{5}{|l|}{ CRC T stage } \\
\hline T0 & Reference & & & \\
\hline $\mathrm{T} 1$ & $0.92(0.02-40.70)$ & 0.966 & & \\
\hline T2 & $1.14(0.03-49.01)$ & 0.947 & & \\
\hline T3 & $1.26(0.04-39.01)$ & 0.895 & & \\
\hline $\mathrm{T} 4$ & $2.35(0.06-101.05)$ & 0.657 & & \\
\hline \multicolumn{5}{|l|}{ CRC LN metastasis } \\
\hline No & Reference & & Reference & \\
\hline Yes & $5.81(1.13-29.98)$ & $0.036^{\star}$ & $5.44(0.72-41.29)$ & 0.102 \\
\hline
\end{tabular}


Table 4. Continued

\begin{tabular}{|c|c|c|c|c|}
\hline \multirow{2}{*}{ Variable } & \multicolumn{2}{|c|}{ Univariate analysis } & \multicolumn{2}{|c|}{ Multivariate analysis } \\
\hline & HR $(95 \% \mathrm{Cl})$ & $P$-value & $\mathrm{HR}(95 \% \mathrm{Cl})$ & P-value \\
\hline \multicolumn{5}{|c|}{ BrC TNM stage } \\
\hline 0 & Reference & & & \\
\hline 1 & $0.96(0.100-9.37)$ & 0.969 & & \\
\hline 2 & $1.01(0.09-11.65)$ & 0.994 & & \\
\hline 3 & $1.92(0.12-31.53)$ & 0.647 & & \\
\hline \multicolumn{5}{|c|}{ CRC TNM stage } \\
\hline 0 & Reference & & & \\
\hline 1 & $0.54(0.01-21.73)$ & 0.746 & & \\
\hline 2 & $0.69(0.02-26.96)$ & 0.844 & & \\
\hline 3 & $2.45(0.09-68.03)$ & 0.598 & & \\
\hline
\end{tabular}

HR, hazard ratio; Cl, confidence interval; BrC, breast cancer; CRC, colorectal cancer; CEA, carcinoembryonic antigen; CA 15-3, carcinoma antigen 15-3; IDC, invasive ductal carcinoma; HER2, human epidermal growth factor receptor 2; LN, lymph node.

${ }^{a}$ Estrogen or progesterone.

${ }^{*} \mathrm{P}<0.05$.

be of significance in determining the appropriate adjuvant treatment for those with double primary cancers.

This study evaluated the clinicopathologic outcomes in patients with double primary cancers of $\mathrm{BrC}$ and CRC. However, there are several limitations. First, this study was based on retrospective data with a heterogeneous and small study population. The results of the multivariate analysis for overall survival with no statistical significance may be attributed to these limitations. A large cohort study is required to validate the outcomes of this study. Second, the patients included were only from Asia, especially Korea. The racial differences for the phenotypes of $\mathrm{BrC}$ and $\mathrm{CRC}$ should be considered in interpreting our outcomes in future studies. Third, adjuvant therapies for both $\mathrm{BrC}$ and $\mathrm{CRC}$ were not unified because of the long-term study period. As the development of chemotherapeutics and diagnostic tools advances, it cannot be excluded since this may also affect certain outcomes. However, this study is crucial in analyzing the clinicopathologic characteristics and prognosis of double primary cancer patients who were diagnosed with both $\mathrm{BrC}$ and $\mathrm{CRC}$.

In conclusion, in the metachronous double primary cancers of both $\mathrm{BrC}$ and $\mathrm{CRC}$, the $\mathrm{B}$-first group had a poorer prognosis than the C-first group. HER2 positivity and CRC LN metastasis can be considered prognostic factors for overall survival in these patients. These findings suggest that CRC screening program needs to be included during $\mathrm{BrC}$ surveillance. In addition, $\mathrm{BrC}$ patients need to pay more attention to CRC screenings in consideration of the poorer overall survival of the $\mathrm{B}$-first group than the $\mathrm{C}$-first group.

\section{CONFLICT OF INTEREST}

No potential conflict of interest relevant to this article was reported.

\section{FUNDING}

None.

\section{ACKNOWLEDGMENTS}

This study was supported by the Basic Science Research Program through the National Research Foundation of Korea (NRF) funded by the Ministry of Science and ICT (NRF-2019R1I1A1A01058889 and NRF-2021R1A2C1012853), and a Faculty Research Grant of Yonsei University College of Medicine (6-20190179).

\section{SUPPLEMENTARY MATERIALS}

Supplementary materials for this study are presented online (available at https://doi.org/10.3393/ac.2021.00640.0091).

\section{REFERENCES}

1. Vogt A, Schmid S, Heinimann K, Frick H, Herrmann C, Cerny T, et al. Multiple primary tumours: challenges and approaches, a review. ESMO Open 2017;2:e000172.

2. Amer MH. Multiple neoplasms, single primaries, and patient survival. Cancer Manag Res 2014;6:119-34.

3. Buiatti E, Crocetti E, Acciai S, Gafà L, Falcini F, Milandri C, et al. Incidence of second primary cancers in three Italian populationbased cancer registries. Eur J Cancer 1997;33:1829-34.

4. Jung KW, Won YJ, Kong HJ, Lee ES; Community of PopulationBased Regional Cancer Registries. Cancer Statistics in Korea: incidence, mortality, survival, and prevalence in 2015. Cancer Res Treat 2018;50:303-16. 
5. Siegel RL, Miller KD, Jemal A. Cancer statistics, 2019. CA Cancer J Clin 2019;69:7-34.

6. Kmet LM, Cook LS, Weiss NS, Schwartz SM, White E. Risk factors for colorectal cancer following breast cancer. Breast Cancer Res Treat 2003;79:143-7.

7. Abu-Sbeih H, Ali FS, Ge PS, Barcenas CH, Lum P, Qiao W, et al. Patients with breast cancer may be at higher risk of colorectal neoplasia. Ann Gastroenterol 2019;32:400-6.

8. Lu Y, Segelman J, Nordgren A, Lindström L, Frisell J, Martling A. Increased risk of colorectal cancer in patients diagnosed with breast cancer in women. Cancer Epidemiol 2016;41:57-62.

9. Sanchez-Mete L, Venturo I, Papaldo P, Sperduti I, Stigliano V. Colorectal cancer after breast cancer: a case-control study. Cancer Epidemiol 2011;35:44-7.

10. Shukla A, Shukla S, Osowo A, Mashtare T, Bhutani MS, Guha S. Risk of colorectal adenomas in women with prior breast cancer. Dig Dis Sci 2012;57:3240-5.

11. Tang LY, Nugent Z, Demers AA, Singh H. Incidence of right-sided colorectal cancer after breast cancer: a population-based study. Am J Gastroenterol 2009;104:1213-20.

12. Lai JH, Park G, Gerson LB. Association between breast cancer and the risk of colorectal cancer. Gastrointest Endosc 2017;86: 429-41.e1.

13. Pande M, Joon A, Brewster AM, Chen WV, Hopper JL, Eng C, et al. Genetic susceptibility markers for a breast-colorectal cancer phenotype: Exploratory results from genome-wide association studies. PLoS One 2018;13:e0196245.

14. Fisher CS, Wachtel MS, Margenthaler JA. Outcomes for patients who develop both breast and colorectal cancer. Ann Surg Oncol 2012;19:242-8.

15. Cho N. Molecular subtypes and imaging phenotypes of breast cancer. Ultrasonography 2016;35:281-8.

16. Amin MB, Edge SB, Greene FL, Byrd DR., Brookland RK, Wash- ington MK, et al. AJCC Cancer Staging Manual. New York: Springer International Publishing; 2018.

17. Buiatti E, Crocetti E, Acciai S, Gafà L, Falcini F, Milandri C, et al. Incidence of second primary cancers in three Italian populationbased cancer registries. Eur J Cancer 1997;33:1829-34.

18. Hur H, Oh CM, Won YJ, Oh JH, Kim NK. Characteristics and survival of Korean patients with colorectal cancer based on data from the Korea Central Cancer Registry Data. Ann Coloproctol 2018;34:212-21.

19. Nam S, Choi YJ, Kim DW, Park EC, Kang JG. Risk factors for colorectal cancer in Korea: a population-based retrospective cohort study. Ann Coloproctol 2019;35:347-56.

20. Son BH, Kwak BS, Kim JK, Kim HJ, Hong SJ, Lee JS, et al. Changing patterns in the clinical characteristics of Korean patients with breast cancer during the last 15 years. Arch Surg 2006;141:15560.

21. Zhao XB, Ren GS. Diabetes mellitus and prognosis in women with breast cancer: a systematic review and meta-analysis. Medicine (Baltimore) 2016;95:e5602.

22. Petrelli F, Ghidini M, Rausa E, Ghidini A, Cabiddu M, Borgonovo $\mathrm{K}$, et al. Survival of colorectal cancer patients with diabetes mellitus: a meta-analysis. Can J Diabetes 2021;45:186-97.e2.

23. Chapman JA, Meng D, Shepherd L, Parulekar W, Ingle JN, Muss $\mathrm{HB}$, et al. Competing causes of death from a randomized trial of extended adjuvant endocrine therapy for breast cancer. J Natl Cancer Inst 2008;100:252-60.

24. Greally M, Kelly CM, Cercek A. HER2: an emerging target in colorectal cancer. Curr Probl Cancer 2018;42:560-71.

25. Meric-Bernstam F, Hurwitz H, Raghav KP, McWilliams RR, Fakih M, VanderWalde A, et al. Pertuzumab plus trastuzumab for HER2-amplified metastatic colorectal cancer (MyPathway): an updated report from a multicentre, open-label, phase 2a, multiple basket study. Lancet Oncol 2019;20:518-30. 